\title{
SITUATION OF LENINGRAD CHILDREN EVACUATED FROM THE BESIEGED CITY IN YAROSLAVL REGION (1941-1945)
}

\author{
Elena Yu. Volkova \\ Kostroma State University, Kostroma, Russian Federation
}

\begin{abstract}
Introduction. The siege of Leningrad is one of the most tragic pages in the history of the Great Patriotic War. The whole country took part in helping residents of the besieged city. Yaroslavl Region was one of the leading places where tens of thousands of children were evacuated. Methods and materials. The author seeks to implement the principles of scientific objectivity and reliability. The article is based on the memories of eyewitnesses of those years and archival materials. The author had an invaluable help in understanding the atmosphere in which children lived through confidential conversations with survivors of the blockade. Their stories are shocking in their naked truth. The author uses the comparative historical method in disclosing new, qualitative aspects of the problem under study. The hermeneutic method is used in the analysis of various sources: archival materials, memories, letters, first of all, based on time and reasons for the appearance of a particular source. The anthropological approach to the problem makes it possible to create a socio-psychological portrait of children, who by fate turned out to be far from their home, to recreate a picture of their life and everyday life. Analysis. It includes the problems associated with the children evacuation in July-August 1941 and especially in winter-spring 1942, raises the issue of child mortality and the perpetuation of their memory. Results. A major role in the organization of children's life was played by the party and the Soviet leadership. The article notes that ordinary workers and collective farms took the successful solution of domestic problems of orphans. They provided children with everything they needed: home, food, clothes, shoes, dishes, etc. In addition, citizens took children on patronage and adoption. The methods of educational work with them had changed, where one of the main directions was the inculcation of labour skills: children worked in their farms, helped collective farms, cleaned their homes, were engaged in needlework, worked in workshops, etc. The desire to live and create was instilled in Leningrad by attracting citizens to participate in art performances. Big problems are connected with statistical data, in particular, different sources give different numbers of children living on the territory of Yaroslavl region: from 90 to 150 thousand. It is almost impossible to count the number of dead children, so the established monuments to small Leningraders, as a rule, are nameless. After the lifting of the blockade some children returned to Leningrad, and some linked their destinies with Yaroslavl land.
\end{abstract}

Key words: Leningrad, blockade, children, Yaroslavl region, orphanages, party and Soviet leadership.

Citation. Volkova E.Yu. Situation of Leningrad Children Evacuated from the Besieged City in Yaroslavl Region (1941-1945). Vestnik Volgogradskogo gosudarstvennogo universiteta. Seriya 4. Istoriya. Regionovedenie. Mezhdunarodnye otnosheniya [Science Journal of Volgograd State University. History. Area Studies. International Relations], 2020, vol. 25, no. 1, pp. 59-69. (in Russian). DOI: https://doi.org/10.15688/jvolsu4.2020.1.5 
одно из ведущих мест, куда были эвакуированы десятки тысяч детей. Статья основывается на воспоминаниях очевидцев тех лет и архивных материалах. В ней прослеживаются проблемы, связанные с эвакуацией детей в июле - августе 1941 г. и особенно зимой - весной 1942 г., поднимается вопрос о смертности детей и увековечивания их памяти. Большую роль в организации жизни детей сыграло партийное и советское руководство на местах. В статье отмечается, что успешное решение бытовых проблем детдомовцев взяли на себя простые труженики, а также колхозы, которые предоставили детям все необходимое: помещение, пищу, одежду, обувь, посуду и др. Кроме того, ярославцы брали детей на патронирование или усыновление. Изменились методы воспитательной работы с ними, где одним из главных направлений стало привитие трудовых навыков: дети трудились в своих подсобных хозяйствах, помогали колхозам, убирали свои жилые помещения, занимались рукоделием, работали в мастерских и т. д. Желание жить и творить прививалось ленинградцам путем привлечения их к участию в художественной самодеятельности. Большие проблемы связаны со статистическими данными, в частности, в разных источниках дается разное число проживавших на территории Ярославской области детей - от 90 до 150 тысяч. Практически невозможно сосчитать количество умерших детей, поэтому установленные памятники маленьким ленинградцам, как правило, безымянные. После снятия блокады часть детей вернулись в Ленинград, а часть связали свою судьбу именно с Ярославской землей.

Ключевые слова: Ленинград, блокада, дети, Ярославская область, детдома, партийное и советское руководство.

Цитирование. Волкова Е. Ю. Положение ленинградских детей, эвакуированных из блокадного города, в Ярославской области (1941-1945 гг.) // Вестник Волгоградского государственного университета. Серия 4, История. Регионоведение. Международные отношения. - 2020. - Т. 25, № 1. - C. 59-69. - DOI: https://doi.org/ 10.15688/jvolsu4.2020.1.5

Введение. Тема эвакуации населения в тыловые регионы страны привлекала внимание ученых уже в период Великой Отечественной войны. Однако до сих пор остается много белых пятен, начиная с терминологии и заканчивая реэвакуацией. Причины тому есть объективные (до сих пор много документов остаются засекреченными, возникают большие проблемы со статистикой и др.) и субъективные (ученые обращают больше внимания на другие аспекты). Радует, что архивы, в том числе Ярославской области, стали публиковать в Интернете некоторые документы по данной теме, однако пока их крайне мало для создания объективной картины происходившего [20;21]. К практически не изученным относится и тема эвакуации из Ленинграда детей в Ярославскую область, их устройство на новом непривычном месте, жизнь и реэвакуация. Кроме того, до недавнего времени не поднимался вопрос о численности умерших детей в эвакуации и причинах их смертности. В связи с этим автор, основываясь прежде всего на архивных материалах, поднимает вопрос об эвакуации детей в Ярославскую область, рассматривает проблемы, с которыми дети столкнулись в тылу, а также какую роль сыграло местное руководство и население в жизни маленьких ленинградцев.
Методы. Автор стремится в максимально возможной мере реализовывать принципы научной объективности и достоверности. Научная объективность требует всестороннего и глубокого анализа источников, проверки и сопоставления мнений разных авторов исторических работ. Неоценимую помощь в понимании атмосферы, в которой находились дети, оказали доверительные беседы автора с людьми, пережившими блокаду. Их рассказы потрясают своей неприкрытой правдой. Только стремление к научной объективности позволяет в таких случаях сохранять требуемую беспристрастность и руководствоваться гуманистическими, общечеловеческими ценностями, правовыми и нравственными оценками явлений того времени.

В работе используются общенаучные методы исследования (исторический и метод классификации), а также специальные и междисциплинарные. Сравнительно-исторический метод автор применяет при раскрытии новых качественных сторон изучаемой проблемы. Герменевтический метод используется при анализе различных источников: архивных материалов, воспоминаний, писем, отталкиваясь в первую очередь от времени и причины появления конкретного источника. При этом главная задача заключается в том, чтобы дать им необходимую оценку в контексте изучае- 
мой эпохи в целях максимальной объективности их интерпретации. Ситуационный подход дает возможность избежать искусственной модернизации в оценках изучаемой проблемы. Автор уделяет внимание показу событий, восприятию их современниками в контексте конкретно-исторической ситуации войны. В то же время слишком пристальное внимание к историко-ситуационному подходу ведет к односторонности и архаизации оценок. Поэтому, столь же необходим взгляд с исторической дистанции, когда уже проявились долговременные результаты прошедших событий. Важное методологическое значение имеет системный подход. Он является основой для аналитических обобщений и научной иерархизации собранного исторического материала. С опорой на него были выявлены связи наиболее значимых факторов, повлиявших на положение детей. Антропологический подход к проблеме позволил создать социально-психологический портрет детей, волей судьбы оказавшихся далеко от родного дома, воссоздать картину их жизни и повседневного быта.

Анализ. Блокада Ленинграда - одна из самых героических и трагических страниц периода Великой Отечественной войны. Вся страна приняла участие в помощи жителям блокадного города. Особой заботой стала эвакуация и размещение детей в тылу. Одним из основных регионов, куда направлялись дети, стала Ярославская область ${ }^{1}$. В соответствии с решением исполкома Ленгорсовета от 29 июня 1941 г. «О вывозе детей из Ленинграда в Ленинградскую и Ярославскую области» предполагалось вывезти около 400 тыс. человек. Однако быстрое наступление врага привело к тому, что эвакуация в районы Ленинградской области была прекращена. В соответствии с решением Ярославского облисполкома от 14 июля 1941 г. организация всей работы с детьми возлагалась на облоно и его местные органы, с детьми ясельного возраста - на облздравотдел, уполномоченные от Ленинградского гороно стали заместителями заведующих районных и областного отделов народного образования.

Уже в июле 1941 г. в Ярославскую область привезли 47465 ленинградских детей $[19$, л. 161]. В итоге число детдомов вы- росло в 17 раз: с 25 в июне до 425 в августе. Под них были отданы все свободные здания: дома отдыха, санатории, 190 школ, 1100 домов, принадлежавших колхозам и колхозникам [7, с. 9]. Но расселение детей являлось только первым шагом. Многие детдома прибывали без постельных принадлежностей, белья, посуды, а некоторые приехали с пустыми руками. И все это им нужно было предоставить. Но местные власти по объективным, а порой и субъективным причинам не смогли обеспечить детей всем необходимым. Руководство области старалось быстро реагировать. 7 июля 1941 г. в письме председателям райисполкомов первый секретарь обкома партии Н.С. Патоличев и председатель облисполкома А.А. Гогосов отмечали: «Наблюдаются случаи плохой организации обслуживания детей, эвакуированных из Ленинграда, в результате чего отдельные ребята бегут на фронт, купаются в неположенных местах, что приводит к несчастным случаям. Обязываем вас систематически наблюдать через органы народного образования за состоянием ухода и организацией воспитательной работы в эвакуированных учреждениях. Работников, нерадиво относящихся к своим обязанностям, нарушающих трудовую дисциплину, не организующих наблюдение за детьми и воспитательной работы, немедленно снимайте с работы и направляйте обратно в Ленинград, заменяя их местными работниками. Организуйте использование всех ребят старше 11-летнего возраста на сельхозработах в колхозах и совхозах, на лесных работах - охрана, расчистка и других посильных для ребят работах. Предупреждаем о Вашей личной ответственности за состояние и воспитание эвакуированных детей, размещенных по Вашему району» $[17$, л. 4].

Но и дети не все оказывались подготовленными к жизни вдали от родителей в сельской местности. В письмах они жаловались на плохие условия, неорганизованный быт и просто просили их забрать и увезти домой. В итоге за ними стали приезжать родители. Для улучшения положения детей в конце июля 1941 г. вопрос о работе среди них был поставлен на бюро обкома ВКП(б), которое предлагало размещать эвакуированных девочек и мальчиков по селам, освободить школьные 
здания, чтобы дети могли учиться, в воспитательной работе обратить «особое внимание на привитие детям трудовых навыков», организовать пионерскую работу. Особо было отмечено «считать ненормальным участившиеся случаи обратного увоза детей в г. Ленинград под предлогом плохих условий жизни детей в Ярославской области... проверять на месте причины увоза детей и рассеивать провокационные слухи о голоде, эпидемиях и “издевательстве" над детьми». Обком просил Ленинградский горком партии дать указания не отпускать матерей за детьми [13, л. 7-8].

Подобные вопросы поднимались в каждом районе области. Например, Даниловский райком партии 16-17 июля отмечал, что дети местами расположены скученно, в силу чего возможны эпидемиологические заболевания, в ряде мест питание поставлено неудовлетворительно, среди обслуживающего персонала встречается нарушение дисциплины [10, л. 77]. 15 июля вопрос о воспитательной работе с детьми поставил Любимский РК ВКП(б). Райком подчеркнул, что работа поставлена плохо, комсомол не включился в работу с детьми, ленинградцы слабо привлекаются к трудовым работам. Отсюда происходило нарушение дисциплины: самовольный уход в кино, отказ от работы, побеги, кражи, хулиганство.

После всесторонней проверки работы детучреждений 16 августа районное бюро вновь подняло этот вопрос, где было отмечено улучшение воспитательной работы. Теперь в ней сделаны акценты на привитие трудовых навыков, оздоровительные мероприятия, военно-физкультурную работу, экскурсионно-туристическую, политико-воспитательную. В разделе общественно-полезной работы особое место уделили участию ребят в полевых работах. За ними были закреплены колхозы. 12-15-летних разбили на звенья или бригады, которые трудились по 6-8 часов. Например, 65 ребят ленинградской школы № 153 ежедневно вытеребляли по 5 га льна, учащиеся школы № 157 ударно трудились на заготовке веточного корма. Бюро также констатировало, что все детсады находились в хороших жилищно-бытовых условиях. Детей регулярно мыли, постригли наголо девочек и мальчиков до 10 лет, провели дезинфекцию одежды.
Но еще не везде закончили ремонт, не хватало кухонного инвентаря, а также одежды и обуви [11, л. 80-81, 118].

В конце августа представители Ярославского обкома союза работников дошкольных учреждений и детдомов вместе с уполномоченным Ленинградского исполкома обследовали пять районов, где сосредоточилось наибольшее число детсадов, эвакуированных из Ленинграда: Борисоглебский - 541 человек, Буйский - 2 744, Даниловский - 1 049, Некоузский -3332 , Тутаевский - 1837 . Комиссия сделала вывод, что дети неплохо размещены, но при переходе на зимний период будут затруднения: дети жили в школах, которые нужно было освобождать, а ленинградцев расселять по домам колхозников. Половина детей спали еще без кроватей. Были случаи, когда дети в изоляторе спали по двое на скамейках. Отмечался большой недостаток кухонной посуды. Питание было налажено, но испытывали дефицит в овощах и молоке. «Местное население очень внимательно и заботливо... воспитатели много внимания уделяют беседам о военных действиях, но много прогулов и совершенно отсутствуют трудовые занятия и пение» [2, л. 17].

В Козловском сельсовете Ростовского района были размещены 575 детей. Все дети были вымыты и расселены по колхозным домам. На первых порах в детдомах не было весов, продукты отпускались «на глазок». Бывали случаи, когда дети вместе с руководителями просили хлеба у колхозников, так как неделю им не выделяли продукты. Также не хватало кроватей, постельных принадлежностей. В колхозе «Комбинат» размещено 258 детей, из них 60 \% обеспечены койками и постельными принадлежностями, а остальные спят на матрацах на полу. Но к концу июля стало все налаживаться [12, л. 501].

В итоге четкие действия местных властей спасли от смерти многих ленинградских детей. И, тем не менее, в августе 1941 г. 20211 детей уехали обратно в Ленинград [3, л. 112]. Судьба их в блокированном городе остается неизвестной.

Следующий вынужденный этап эвакуации ленинградских детей уже из Ярославской области далее в тыл наступил в октябре 1941 г., когда для области возникла угроза ок- 
купации. В соответствии с решением Совета по эвакуации при СНК СССР от 23 октября «Об эвакуации детей Ленинграда из Ярославской области» 28 октября облисполком решил эвакуировать 14324 детей водным транспортом в Молотовскую область, 12612 - железнодорожным в Челябинскую и 11174 - в Омскую. Каждый ребенок получил продукты на 10 дней: 300 г сливочного масла, по 500 г сыра и колбасных изделий, банку сгущенного молока и 30 рублей [3, л. 100]. В итоге в октябре 1941 г. было вывезено вглубь страны 39922 ленинградца [9, л. 141]. На 1 января 1942 г. в области оставалось 7543 ребенка из Ленинграда [19, л. 161].

Для оставшихся в области детей продолжилась работа по подготовке к зиме, организации их питания. По решению облисполкома от 13 сентября 1941 г. для ленинградских детей выделили 460 тыс. руб. на ремонт помещений и 1040 тыс. на одежду [18, л. 80]. 29 ноября облисполком уточнил нормы продуктов на каждого ребенка в день: 500 г хлеба ржаного, по 50 г белой муки, круп, рыбы или мяса, по 30 г масла сливочного или растительного и моркови, по 20 г сахара, сыра, колбасы, свеклы и лука, 350 г молока, 500 г картофеля, 300 г капусты, 1 г чая и 200 г мыла на месяц [18, л. 105]. Однако утвержденная норма в 5 руб. в день фактически не превышала 3 руб. 15 коп. Дети недополучали молочных продуктов, овощей, кондитерских изделий. Например, в Антроповском районе в декабре 1941 г. израсходовали на каждого из 1461 детдомовца молока 67 г в день при норме 500 г, муки соответственно - 32 и 40, манной крупы 5 и 30 , конфет -10 и 40 , мяса -3 и 25 , картофеля 200 и 500 , масла $-1,5$ и 200 г. В Палкинском районе ассигнования на питание детей должны были составлять 4 руб. в день, а получалось лишь 1 руб. 40 коп. - 1 руб. 80 коп. В итоге состояние детей, вывезенных из Ленинграда в основном здоровыми, ухудшилось. Шесть человек заболели туберкулезом, 21 - малокровием [9, л. 2, 140].

Однако самое тяжелое было впереди. С конца января 1942 г. в область стали поступать дети, пережившие блокаду. Для их размещения и трудоустройства была создана областная комиссия во главе с заместителем председателя облисполкома А.Н. Никитиной.
Секретарь обкома ВЛКСМ А.П. Пелевин наставлял: «На Ярославской земле ленинградские дети не должны чувствовать себя сиротами; надо сделать все возможное и невозможное, чтобы дети скорее поправились, радовались жизни» [7, с. 72].

В 1942 г. с конца января до середины мая в область прибыло 5800 ребятишек в составе детучреждений и 14991 - с родителями и просто снятых с эшелонов. На 15 мая всего в области находились 35087 детей [24, с. 275]. На 25 сентября в 30 из 39 районов области насчитывалось 214 детдомов. Им предоставили 439 зданий, из них 26 детдомов, 97 школ, 32 помещения политпросветучреждений (клубы, избы-читальни, дома отдыха), две бывшие церкви, 53 дома колхозников. Из-за нехватки площадей некоторые располагались в нескольких зданиях [9, л. 141]. 270 врачей день и ночь боролись за маленькие жизни. Дети поправлялись очень медленно. Труднее было вылечить их не от дистрофии, а от нервного потрясения. Ольга Акимовна Царапкина, директор детдома № 7 в Ярославле, вспоминала: «Сначала детский дом был больше похож на лазарет. Дети просто лежали, очень часто уединялись и сидели в глубокой задумчивости. Они боялись любого шума или стука. Многие не расставались с вещами погибших родителей» [5].

Следующим шагом стало налаживание всех сторон жизни детей. Бюро обкома ВКП(б) в апреле 1942 г., рассматривая вопрос «О состоянии детских домов в области», постановило организовать при каждом детдоме мастерские по труду и подсобные хозяйства, популяризировать создание интернатов в колхозах, оказывать шефскую помощь [15, л. 10-12].

Возникало много проблем в обеспечении детей всем необходимым. Большую работу по налаживанию быта проделали районные партийные и советские организации. Все, что смогли, выделили из фондов области, что-то изготовили на предприятиях местной промышленности. Тем не менее этого было недостаточно. Особенно плохо было с кожаной обувью и валенками: требовалось 15 тыс. ботинок, а было в наличии 867 шт., валенок соответственно - 20 тыс. и 1 тыс. шт. В октябре - ноябре 1942 г. по распоряжению СНК РСФСР для ле- 
нинградских детей было выдано 9 тыс. пар валенок, на 500 тыс. руб. кожаной и резиновой обуви, на 250 тыс. - хлопчатобумажной ткани, 2,5 млн руб. деньгами на пошив одежды и обуви. По распоряжению заместителя председателя СНК РСФСР А.Н. Косыгина дополнительно выдано 10 тыс. пар валенок, 15 т ваты и 15 тыс. м ткани [3, л. 113, 141]. Несмотря на принятые меры, не хватало продуктов. В третьем квартале 1942 г. по области полагалось детдомам 79,2 т мяса, но дали 45, рыбы - 15,6 и 10 соответственно, сухарей и кондитерских изделий $-38,2$ и 13 , жиров - 53,9 и 33 , макаронных изделий $-48,8$ и 15 [9, л. 98].

Жители области с большой любовью и теплотой отнеслись к детям. По инициативе комсомольцев в области развернулось движение за сбор средств в помощь детям, оставшимся без родителей. Деньги получали от проведенных воскресников, дополнительных киносеансов, вечеров самодеятельности, добровольных взносов, отчислений из зарплаты. Но этого было мало. В марте 1942 г. труженики колхоза «Красная звезда» Ярославского района во главе с председателем В.И. Шакуриным приняли решение открыть при колхозе интернат для ленинградских детей, потерявших своих родителей. Колхозники писали: «В неограниченном количестве для наших воспитанников дадим мяса, молока, масла и других продуктов, оденем и обуем их с ног до головы. Для общего руководства и воспитательной работы в интернате выделена лучшая общественница комсомолка М. Смородинова». Обком партии поддержал инициативу колхозников и предложил остальным использовать их опыт, но предупредил, чтобы в этом «всесторонне учитывать возможности колхозов, предприятий, организаций и семей... не допускать поспешного и непродуманного отношения к этому важнейшему делу» $[14$, л. 22-23, 48-49]. Сначала 12 семилетних девочек разместили по домам колхозников в д. Окишино, а затем на берегу реки построили просторный дом. Дети были крайне ослаблены. Но уже в течение первого месяца прибавили от 1,5 до 1,8 кг. Всего за счет средств общественности области был создан 31 интернат, где воспитывалось свыше тысячи детей. В селе Глебово Рыбинского района для детей со слабым здоровьем был открыт спе- циальный детдом на 300 коек. В Некоузском районе организован межколхозный санаторий для детей больных туберкулезом, где лечились и ленинградцы, в Ярославском в наиболее сильных колхозах стали действовать пять интернатов на 25-30 человек [3, л. 13].

При обкоме союза работников дошкольных учреждений был создан институт уполномоченных, который занимался устройством детей, оставшихся без родителей. Ярославский отдел народного образования выпустил листовку «Возьмем на воспитание и усыновление детей, оставшихся без родителей», где говорилось: «Забота о пострадавших детях святое, благородное, подлинно патриотическое дело. Чем больше осиротевших детей найдут сейчас семью, ласку и любовь, тем быстрее будут устранены тяжелые последствия войны». В ней в сжатой форме описывалась процедура усыновления, например, были разделы: «Кто и как может взять ребенка на воспитание», «Как усыновить ребенка» [3, л. 103]. К 1944 г. в области было усыновлено, находилось на патронировании и опеке около 3200 детей. Всего за войну трудящиеся области взяли в свои семьи на воспитание 2626 детей и усыновили 463 ребенка [7, с. 12].

Поскольку основное количество детдомов располагалось в сельской местности, большая роль в оказании им шефской помощи отводилась колхозам. На первом этапе она выражалась в снабжении детей продуктами, обеспечении дровами, затем стали ремонтировать помещения, готовить их к зиме, изготавливать или приобретать мебель, постельное и нательное белье, обувь и одежду. Весной 1942 г. колхозники начали засевать сверхплановые гектары. Обком партии не только поддержал, но и 21 сентября 1942 г. принял специальное решение об организации всеобщего охвата детдомов шефской помощью. Все районы подключились к его выполнению. Как это происходило, можно проследить на примере Некрасовского района. В докладной записке в обком было сказано, что в районе действует восемь детдомов, где живут 1047 детей из Ленинграда. Райком «развернул во всех колхозах и предприятиях массовую работу, в результате чего к середине ноября над каждым детдомом принято шефство колхозами... Все дома были обеспечены кол- 
хозами и предприятиями в полной потребности кроватками, посудой, одеялами, простынями, наволочками и др., частично приобретена обувь и одежда». На период весеннего сева 1942 г. всем домам выделены от 4 до 25 га земли, лошади, семена. В результате к осени каждый детдом имел своих запасов овощей и картофеля на восемь месяцев, а также по 710 поросят, от 30 до 100 штук разной птицы, некоторые по 5-10 овец, 2-5 коров. Кроме того в овощехранилищах колхозов были заложены специальные фонды овощей и картофеля для детдомов до следующего урожая [9, л. 19]. Итогом проделанной большой работы стало то, что к концу 1943 г. 500 колхозов области оказывали шефскую помощь детдомам.

Однако для полноценного снабжения продуктами детдомов шефской помощи было недостаточно. С начала войны создавались собственные подсобные хозяйства. Но в 1941 г. их земельная площадь составила лишь 353,25 га. Несмотря на решение облисполкома от 27 марта 1942 г. «О развитии подсобных хозяйств при детдомах» в 1942 г. площадь довели до 533,45 га, что тоже было мало [3, л. 21]. В феврале 1943 г. уже областной комитет партии в более жесткой форме постановил создать при каждом детучреждении подсобное хозяйство, обязал выделить им 7411 га, в том числе 1474 га - под овощи и картофель, 480 - под зерно и 5557 - под сенокосы. При этом обеспечить семенами, крупным рогатым скотом, хозпостройками, изготовить сельхозинвентарь [16, л. 32-33]. После этого движение пошло более быстрыми темпами. В 1943 г. детдомовцы засеяли овощами и зерновыми 1742 га, приобрели 122 лошади, 420 коров, 698 овец, 320 свиней [7, с. 54].

Учитывая изменившиеся условия жизни детей, их психологическое состояние, пришлось перестраивать с ними воспитательную работу. Большую роль в желании жить и творить стало участие детей в созданных кружках художественной самодеятельности. Они выступали не только перед своими ребятами, но и перед местным населением. В ноябре 1943 г. в ярославском Дворце пионеров состоялся концерт воспитанников детских домов, переживших блокаду.

Одним из важнейших элементов воспитательной работы стало привитие трудовых навыков. Дети сами убирали помещения, носили воду, заготавливали и кололи дрова, делали полочки и табуретки, шили белье. При активном участии шефствовавших колхозов и промпредприятий при детдомах в 1943 г. были созданы 38, а к середине 1944 г. - 85 швейных, трикотажных, слесарных, столярных, сапожных и других мастерских, в которых занималось более тысячи детей. В них они изготавливали вещи не только для себя, но и на заказ. В обязанности детдомовцев входила помощь колхозам. В 1943 г. по всей области дети и воспитатели выработали 140 тыс. трудодней [3, л. 146]. Например, ленинградские дети, воспитывавшиеся в детдоме № 35 Нейского района, заработали большой авторитет среди сельских жителей. Колхозники одного из хозяйств, располагавшегося за 8 км от детдома, специально пришли к детям и попросили их помочь в уборке урожая: «Покажите колхозникам, как надо работать». Дети вышли рано утром и до обеда 120 человек вытеребили 4 га льна [9, л. 67]. Кроме того, детдома организовывали ясли для детей колхозников на период весенне-осенних работ, помогали проводить в избах-читальнях политическую работу, для колхозников делали доклады, читали газеты.

Пройдя через все испытания, ленинградские дети более ответственно подходили к учебе. Повзрослевших детдомовцев направляли на учебу в профтехучилища, техникумы, институты, рекомендовали в военные училища, устраивали на работу. Многие из них, получив квалификацию, становились прекрасными производственниками.

Постепенно дети восстановили свои физические и душевные силы. К лету 1943 г. в целом по области насчитывалось 224 ленинградских детских учреждений с контингентом в 22229 человек, с которыми работали 1779 воспитателей. Работники детдомов, собравшиеся в 1943 г. на областное совещание, писали ленинградцам: «Теперь мы можем сказать, что дети восстановили и укрепили свое здоровье, стали бодрыми и жизнерадостными, снова зазвучали детские песни и смех. Им возвращено детство» $[7$, с. $14,54,56]$. В целом невозможно сосчитать количество детей, находившихся в Ярославской области. В разных источниках цифра колеблется от 90 до 150 тысяч [22, с. 73; 23, с. 123]. 
С окончанием блокады дети стали возвращаться домой в Ленинград. Но и здесь возникли трудности. О.А. Царапкина говорила: «Когда пришло время расставаться, плакали и дети и взрослые. Дети отвыкли от своих родных. Мне пришлось не только провожать их домой, но и больше месяца жить в Ленинграде в семьях родителей малышей, пока дети не привыкли к своим настоящим папам и мамам». Но вернулись не все. Комуто некуда было возвращаться: квартира была занята другими людьми. Для кого-то слишком сильны были воспоминания, чтобы вернуться, а кто-то просто уже на ярославской земле нашел вторую родину. Но, где бы ни находились воспитанники, они никогда не забывали тех, кто спас их от смерти.

Не все маленькие ленинградцы смогли выжить в эвакуации. Некоторые из них умерли уже по дороге в тыл, у кого-то организм не справился с последствиями блокады, несмотря на всестороннюю помощь. Сколько их похоронено на территории Ярославской и Костромской областей, сосчитать крайне сложно, если вообще возможно. В Государственном архиве Ярославской области хранится рукопись, где приведены списки захороненных ленинградцев на ярославской земле. По ней можно сосчитать, что последствия блокады унесли жизни 3170 детей в возрасте до 17 лет [1, c. 509]. При грантовой поддержке Костромской областной администрации в 2014-2016 гг. был реализован проект «Дети Ленинграда, умершие на территории города Костромы и Костромской области в период Великой Отечественной войны». По данным исследования найдены имена умерших 1044 детей, в том числе 104 - в Костроме. Причем, больше их смертность была зимой 1941/42 г., то есть вывезенных еще до блокады, так как это был период создания «с нуля» детдомов, налаживания системы снабжения и медицинской помощи. Например, в детдоме в с. Контеево Буйского района дети умирали в большинстве своем в возрасте от нескольких месяцев до 2-3 лет из-за скученности, плохого санитарного состояния, простудных заболеваний [6].

Местные жители, похоронив детей в братских могилах, устанавливали памятники. Но в основном они безымянные. Причины тому разные. При эвакуированных, особенно детях, ехавших с родителями или в составе детского дома или сада, не было документов. Кроме того, трупы детей, как и взрослых, снимали на полустанках или просто выбрасывали на ходу поезда. Также это может быть связано с подпиской о неразглашении похоронных бригад - боялись паники. Халатность, невнимание на местах. Когда снимали с поездов много умерших, то даже не успевали их хоронить и тем более выяснять, кто они такие. В ряде случаев известны точные захоронения, а документы на тех, кто в них захоронен, по непонятным причинам пропали.

Инициаторами установления памятников являются разные люди, прежде всего сами блокадники. Например, в Костроме на Лазаревском кладбище 27 января 2011 г. открыт памятник детям блокадного Ленинграда по инициативе Елены Александровны Семенниковой. Когда началась блокада, ей исполнилось 14 лет. Спасло ее от смерти сначала то, что мама еще летом 1941 г. заставляла дочь ездить на окраину города и собирать свекольные листья, которые они засолили в бочке. Но бочка прохудилась, рассол вытек, по квартире разносился нестерпимый запах гниения. Лена не выбросила бочку, а во время блокады к краюшке хлеба добавляла ложечку этих листьев. Затем ее определили в ремесленное училище, а оттуда забрали в воинскую часть, где снабжение было лучше. Тем не менее у Лены развилась цинга, опухали ноги. В 1944 г. ее пришлось эвакуировать в тыл. После войны неравнодушная женщина с большим трудом сумела добиться разрешения поставить памятник детям блокады [4].

Идея создания памятника зарождается у неравнодушных людей, которые даже не жили во время войны. Единственный памятник ленинградским детям в Ярославле на Тверицком кладбище установлен благодаря учителю Вере Викторовне Кузнецовой. Она родилась в 1947 г. в Ярославле. Побывав в Ленинграде на Пискаревском кладбище еще в школьные годы, а затем, работая уже в школе, создавая музей истории школы, она вплотную познакомилась с людьми и документами о детях, эвакуированных в область. Вера Викторовна выступила с идеей возведения памятника, который установили в 1998 г. на пожертвования ярославцев [8]. 
Результаты. Таким образом, трудно назвать постоянное число детей из Ленинграда, воспитывавшихся в Ярославской области, поскольку непрерывно наблюдался следующий процесс: ослабленных ребят принимали, помогали восстановить здоровье, затем часть направляли в другие области, кто-то из них уезжал к родителям, а на их место из блокадного города прибывали новые. Труженики Ярославской области в результате умелого руководства партийных, советских, профсоюзных и комсомольских органов провели огромную работу по спасению ленинградцев, зачастую ухудшая свое и так бедственное положение. Они предоставили эвакуированным все необходимое для восстановления и укрепления физического состояния, создали условия для учебы, а в дальнейшем работы. Но самое главное - простые горожане и колхозники своим теплом, заботой, любовью помогли сохранить высокие морально-нравственные и духовные качества ленинградских детей.

С каждым годом ленинградцев, кто даже в детские годы пережил блокаду, становится все меньше. Но память о них не умрет. Она сохранится в памятниках им, в их воспоминаниях, а это крайне важно для новых поколений России.

\section{ПРИМЕЧАНИЕ}

1 Ярославская область была выделена из Ивановской промышленной области 11 марта 1936 г., куда вошла значительная часть Костромской губернии. По Указу Президиума Верховного Совета СССР от 13 августа 1944 г. была образована Костромская область. В ее состав вошли 26 районов: 15 - из Ярославской области, 3 - из Ивановской, 6 - из Горьковской и 2 - из Вологодской. В связи с этим автор приводит примеры, статистические данные, в том числе и по районам современной Костромской области.

\section{СПИСОК ЛИТЕРАТУРЫ}

1. Вечной памяти достойны... Книга-список эвакуированных ленинградцев, захороненных в Ярославской области в годы Великой Отечественной войны. В 2 т. Т. 2 [Машинописный текст]. - Ярославль, 1996. - 511 с. - (Фонд Государственного архива Ярославской области).
2. Директивные указания и переписка обкома Союза работников дошкольных учреждений и детдомов // Центр документации новейшей истории Государственного архива Ярославской области (ЦДНИ ГАЯО). - Ф. 1054. - ОП. 1. - Д. 65. - 257 л.

3. Документы о состоянии детских учреждений, эвакуированных в Ярославскую область из Ленинграда // Государственный архив Ярославской области (ГАЯО). - Ф. 2224. - ОП. 1. - Д. 81. - 154 л.

4. Из записи бесед с Е.А. Семенниковой // Личный архив Е.Ю. Волковой.

5. Из записи бесед с О.А. Царапкиной // Личный архив Е.Ю. Волковой.

6. Костромская область - территория милосердия. - Электрон. текстовые дан. - Режим доступа: http://deti-leningr-koventr.1gb.ru/childrenlist.aspx (дата обращения: 15.04.2018). - Загл. с экрана.

7. Ленинградцы на волжских берегах: сб. док. и материалов. - Ярославль : Верх.-Волж. кн. изд-во, 1972. $-120 \mathrm{c}$.

8. Невинные ангелы. Как ярославцы спасали детей блокадного Ленинграда. - Электрон. текстовые дан. - Режим доступа: http://www.yar.aif.ru/ society/persona/nevinnye_angely_kak_yaroslavcy_ spasali_detey_blokadnogo_leningrada (дата обращения: 15.04.2018). - Загл. с экрана.

9. О состоянии детдомов в Ярославской области на конец 1942 г. // ЦДНИ ГАЯО. - Ф. 272. Оп. 224. - Д. 667. - 356 л.

10. Протокол заседания бюро Даниловского райкома ВКП(б) // ЦДНИ ГАЯО. - Ф. 244. - Оп. 39. Д. 19. -235 л.

11. Протокол заседания бюро Любимского райкома ВКП(б) // ЦДНИ ГАЯО. - Ф. 248. - Оп. 1. Д. $642 .-138$ л.

12. Протокол заседания бюро Ростовского райкома ВКП(б) // ЦДНИ ГАЯО. - Ф. 272. - ОП. 1. Д. $1168 .-510$ л.

13. Протокол заседания бюро Ярославского обкома ВКП(б) 25-29 июля 1941 г. // ЦДНИ ГАЯО. Ф. 272. - ОП. 224. - Д. 77. - 101 л.

14. Протокол заседания бюро Ярославского обкома ВКП(б) 21-24 марта 1942 г. // ЦДНИ ГАЯО. Ф. 272. - Оп. 224. - Д. 405. - 63 л.

15. Протокол заседания бюро Ярославского обкома ВКП(б) 21-24 апреля 1942 г. // ЦДНИГАЯО. Ф. 272. - Оп. 224. - Д. 412. - 72 л.

16. Протокол заседания бюро Ярославского обкома ВКП(б) 17-26 февраля 1942 г. // ЦДНИ ГАЯО. - Ф. 272. - Оп. 224. - Д. 781. - 67 л.

17. Протоколы по военным вопросам // Государственный архив новейшей истории Костромской области (ГАНИКО). - Ф. 27. - Оп. 1. - Д. 251. - 153 л.

18. Решения Ярославского облисполкома за 1941 г. // Государственный архив Костромского области (ГАКО). - Ф. 1538. - Оп. 22. - Д. 206. - 310 л. 
19. Справки о количестве и трудоустройстве эвакуированного населения из Ленинграда // ЦДНИ ГАЯО. - Ф. 272. - ОП. 224. - Д. 203. - 205 л.

20. Страницы мужества: помощь Ярославской области блокадному Ленинграду. 1941-1944 гг. Электрон. текстовые дан. - Режим доступа: https:// www.yararchive.ru/exhibitions/exhibition-vov70/ (дата обращения: 12.05.2019). - Загл. с экрана.

21. Ярославская земля и блокадный Ленинград. Электрон. текстовые дан. - Режим доступа: http://oldyar.ru/story/98/ (дата обращения: 12.05.2019). - Загл. с экрана.

22. Ярославская область в годы Великой Отечественной войны. - Ярославль : ИПК «Индиго», 2010. $-233 \mathrm{c}$.

23. Ярославская область за 50 лет. 1936-1986: очерки, документы и материалы. - Ярославль : Верх.-Волж. кн. изд-во, 1986. - 326 с.

24. Ярославцы в годы Великой Отечественной войны : сб. док. - Ярославль : Яр. кн. изд-во, 1960. -445 c.

\section{REFERENCES}

1. Vechnoy pamyati dostoyny... Kniga-spisok evakuirovannykh leningradtsev, zakhoronennykh $v$ Yaroslavskoy oblasti v gody Velikoy Otechestvennoy voyny. V 2 t. T. 2 [Mashinopisnyy tekst] [Worthy of Eternal Memory... Book - List of the Evacuated Leningrad Citizens Buried in Yaroslavl Region During the Great Patriotic War. In 2 Vols. Vol. 2 [Typescript]]. Yaroslavl, 1996. 511 p. (Fond Gosudarstvennogo arkhiva Yaroslavskoy oblasti [Fund of the State Archive of Yaroslavl Region]).

2. Direktivnye ukazaniya i perepiska obkoma Soyuza rabotnikov doshkolnykh uchrezhdeniy i detdomov [Policy Directives and Correspondence of the Regional Committee of the Union of Workers of Preschool Institutions and Orphanages]. Tsentr dokumentatsii noveyshey istorii Gosudarstvennogo arkhiva Yaroslavskoy oblasti (TsDNI GAYaO) [Documentation Centre of Modern History of the State Archive of Yaroslavl Region], F. 1054, Op. 1, D. 65.2571 .

3. Dokumenty o sostoyanii detskikh uchrezhdeniy, evakuirovannykh v Yaroslavskuyu oblast iz Leningrada [Documents on the State of Children's Institutions Evacuated to Yaroslavl Region from Leningrad]. Gosudarstvennyy arkhiv Yaroslavskoy oblasti (GAYaO) [State Archive of Yaroslavl Region], F. 2224, Op. 1, D. 81. 1541.

4. Iz zapisi besed s E.A. Semennikovoy [From the transcripts of interviews with E.A. Semennikova]. Lichnyy arkhiv E.Yu. Volkovoy [Personal archive of E.Yu. Volkova].
5. Iz zapisi besed s O.A. Tsarapkinoy [From the Transcripts of Interviews with O.A. Tsarapkina]. Lichnyy arkhiv E.Yu. Volkovoy [Personal Archive of E.Yu. Volkova].

6. Kostromskaya oblast - territoriya miloserdiya [Kostroma Region, the Territory of Mercy]. URL: http://deti-leningr-koventr.1gb.ru/ childrenlist.aspx (accessed 15 April 2018).

7. Leningradtsy na volzhskikh beregakh: sb. dok. $i$ materialov [Leningrad Citizens on the Banks of the Volga. Collection ofDocuments and Materials]. Yaroslavl, Verkhne-Volzhskoe knizhnoe izd-vo, 1972. 120 p.

8. Nevinnye angely. Kak yaroslavtsy spasali detey blokadnogo Leningrada [Innocent Angels. How Yaroslavl Citizens Saved Children of Besieged Leningrad]. URL: http://www.yar.aif.ru/society/persona/ nevinnye_angely_kak_yaroslavcy_spasali_ detey_blokadnogo_leningrada (accessed 15 April 2018).

9. O sostoyanii detdomov v Yaroslavskoy oblasti na konets 1942 g. [On the State of Orphanages in Yaroslavl Region at the End of 1942]. TSDNI GAYaO [Documentation Centre of Modern History of the State Archive of Yaroslavl Region], F. 272, Op. 224, D. 667. 3561.

10. Protokol zasedaniya byuro Danilovskogo raykoma VKP(b) [Minutes of the Meeting of the Bureau of the Danilovskiy District Committee of the All-Union Communist Party (Bolsheviks)]. TsDNI GAYaO [Documentation Centre of Modern History of the State Archive of Yaroslavl Region], F. 244, Op. 39, D. 19. 2351.

11. Protokol zasedaniya byuro Lyubimskogo raykoma VKP(b) [Minutes of the Meeting of the Bureau of the Lyubimskiy District Committee of the All-Union Communist Party (Bolsheviks)]. TsDNI GAYaO [Documentation Centre of Modern History of the State Archive of Yaroslavl Region], F. 248, Op. 1, D. 642. 1381.

12. Protokol zasedaniya byuro Rostovskogo raykoma VKP(b) [Minutes of the Meeting of the Bureau of the Rostov District Committee of the All-Union Communist Party (Bolsheviks)]. TsDNI GAYaO [Documentation Centre of Modern History of the State Archive of Yaroslavl Region], F. 265, Op. 1, D. 1168. 5101.

13. Protokol zasedaniya byuro Yaroslavskogo obkoma VKP(b) 25-29 iyulya 1941 g. [Minutes of the Meeting of the Bureau of the Yaroslavl Regional Committee of the All-Union Communist Party (Bolsheviks) of July 25-29, 1941]. TsDNI GAYaO [Documentation Centre of Modern History of the State Archive of Yaroslavl Region], F. 272, Op. 224, D. 77. 1011.

14. Protokol zasedaniya byuro Yaroslavskogo obkoma VKP(b) 21-24 marta 1942 g. [Minutes of the Meeting of the Bureau of the Yaroslavl Regional Committee of the All-Union Communist Party (Bolsheviks) of Match 21-24, 1942]. TsDNI GAYaO [Documentation Centre of Modern History of the State Archive of Yaroslavl Region], F. 272, Op. 224, D. 405.631.

15. Protokol zasedaniya byuro Yaroslavskogo obkoma VKP(b) 21-24 aprelya 1942 g. [Minutes of the 
Meeting of the Bureau of the Yaroslavl Regional Committee of the All-Union Communist Party (Bolsheviks) of April 21-24, 1942]. TsDNI GAYaO [Documentation Centre of Modern History of the State Archive of Yaroslavl Region], F. 272, Op. 224, D. 412.721.

16. Protokol zasedaniya byuro Yaroslavskogo obkoma VKP(b) 17-26 fevralya $1942 \mathrm{~g}$. [Minutes of the Meeting of the Bureau of the Yaroslavl Regional Committee of the All-Union Communist Party (Bolsheviks) of February 17-26, 1942]. TsDNI GAYaO [Documentation Centre of Modern History of the State Archive of Yaroslavl Region], F. 272, Op. 224, D. 781.671.

17. Protokoly po voennym voprosam [Minutes on Military Issues]. Gosudarstvennyy arkhiv noveyshey istorii Kostromskoy oblasti (GANIKO) [State Archive of Modern History of Kostroma Region], F. 27, Op. 1, D. 251. 1531.

18. Resheniya Yaroslavskogo oblispolkoma za 1941 g. [Decisions of the Yaroslavl Regional Executive Committee for 1941]. Gosudarstvennyy arkhiv Kostromskogo oblasti (GAKO) [State Archive of Kostroma Region], F. 1538, Op. 22, D. 206. 3101.

19. Spravki o kolichestve i trudoustroystve evakuirovannogo naseleniya iz Leningrada
[Documents on Quantity and Employment of Evacuees from Leningrad]. TsDNIGAYaO [Documentation Centre of Modern History of the State Archive of Yaroslavl Region], F. 272, Op. 224, D. 203. 2051.

20. Stranitsy muzhestva: pomoshch Yaroslavskoy oblasti blokadnomu Leningradu. 1941-1944 gg. [Page of Courage: Aid of Yaroslavl Region to Besieged Leningrad. 1941-1944]. URL: https://www.yararchive.ru/ exhibitions/exhibition-vov70/ (accessed 12 May 2019).

21. Yaroslavskaya zemlya i blokadnyy Leningrad [Yaroslavl Land and Besieged Leningrad]. URL: http:// old-yar.ru/story/98/ (accessed 12 May 2019).

22. Yaroslavskaya oblast $v$ gody Velikoy Otechestvennoy voyny [Yaroslavl Region During the Great Patriotic War]. Yaroslavl, IPK «Indigo», 2010. 233 p.

23. Yaroslavskaya oblast za 50 let. 1936-1986: ocherki, dokumenty i materialy [Yaroslavl Region During 50 Years. 1936-1986: Essays, Documents and Materials]. Yaroslavl, Verkhne-Volzhskoe knizhnoe izd-vo, 1986. $326 \mathrm{p}$.

24. Yaroslavtsy v gody Velikoy Otechestvennoy voyny: $s b$. dok. [Yaroslavl Citizens During the Great Patriotic War. Collection of Documents]. Yaroslavl, Yaroslavskoe knizhnoe izd-vo, 1960. 445 p.

\section{Information About the Author}

Elena Yu. Volkova, Doctor of Sciences (History), Associate Professor, Professor, Department of History, Kostroma State University, Dzerzhinskogo St., 17, 156005 Kostroma, Russian Federation, v-0-8@yandex.ru, https://orcid.org/0000-0003-3291-6147

\section{Информация об авторе}

Елена Юрьевна Волкова, доктор исторических наук, доцент, профессор кафедры истории, Костромской государственный университет, ул. Дзержинского, 17, 156005 г. Кострома, Российская Федерация, v-0-8@yandex.ru, https://orcid.org/0000-0003-3291-6147 